\title{
Studies on Effect of Soil Macro and Micronutrient Status of Tamarind (Tamarindus indica L.)
}

\author{
P.S. Urade*, R.M. Dheware and A.R. Jadhav \\ Department of Horticulture, College of Agriculture, Latur \\ Vasantrao Naik Marathwada Krishi Vidyapeeth, Parbhani- 431402 (M.S.) India \\ *Corresponding author
}

\section{Keywords}

Tamarind

(Tamarindusindica

L.), Soil

macronutrient, Soil micronutrient

Article Info

Accepted:

07 January 2019

Available Online:

10 February 2019

\section{A B S T R A C T}

The present investigation was carried out to study the soils macro and micro nutrient status of tamarind orchards in Latur district during the year 2017-2018. The framed experiment was concentrated, to assess and find out the soil nutrient status of tamarind orchards, relation between soil nutrients and yield of sole and bund crops and unfruitfulness of sole crops in tamarind orchards in Marathwada region. Twenty tamarind orchards of eight to thirty five years age planted at different spacing ranging from $8 \times 8 \mathrm{~m}$ to $10 \mathrm{x} 10 \mathrm{~m}$ with plant density of 100 to 150 plant $^{-1} \mathrm{a}^{-1}$ under varied management practices located in different tehsil's of Latur district were selected for the experimentation. In Marathwada region, in sole planting, soil macro-nutrients ranged from $\mathrm{N}\left(129.28\right.$ to $\left.250.00 \mathrm{~kg} \mathrm{ha}^{-1}\right), \mathrm{P}$ (11.00 to $\left.38.00 \mathrm{~kg} \mathrm{ha}^{-1}\right), \mathrm{K}\left(172.00\right.$ to $\left.998.00 \mathrm{~kg} \mathrm{ha}^{-1}\right), \mathrm{Ca}\left(19.00\right.$ to $\left.55.23 \mathrm{cmol}^{(\mathrm{p}+)} \mathrm{kg}^{-1}\right)$, $\mathrm{Mg}$ (186.00 to $\left.397.00^{(\mathrm{p}+)} \mathrm{kg}^{-1}\right)$ and $\mathrm{S}\left(11.25\right.$ to $\left.18.00^{(\mathrm{p}+)} \mathrm{kg}^{-1}\right)$ and soil micro-nutrients ranged from Fe (1.20 to $3.92 \mathrm{mg} \mathrm{kg}^{-1}$ ), Mn (3.51 to $\left.19.78 \mathrm{mg} \mathrm{kg}^{-1}\right), \mathrm{Cu}$ (1.30 to $8.60 \mathrm{mg}$ $\left.\mathrm{kg}^{-1}\right)$, B (0.17 to $\left.1.40 \mathrm{mg} \mathrm{kg}^{-1}\right)$ and $\mathrm{Zn}\left(0.21\right.$ to $\left.2.79 \mathrm{mg} \mathrm{kg}^{-1}\right)$ were observed. However, in bund planting, soil macro-nutrients ranged from $\mathrm{N}\left(137.25\right.$ to $\left.258.01 \mathrm{kgha}^{-1}\right), \mathrm{P}$ (11.01 to $\left.37.25 \mathrm{kgha}^{-1}\right), \mathrm{K}\left(178.11\right.$ to $\left.998.80 \mathrm{kgha}^{-1}\right), \mathrm{Ca}\left(19.20\right.$ to $\left.55.80 \mathrm{cmol}^{(\mathrm{p}+)} \mathrm{kg}^{-1}\right), \mathrm{Mg}(197.80$ to $\left.395 \mathrm{cmol}^{(\mathrm{p}+)} \mathrm{kg}^{-1}\right)$ and $\mathrm{S}\left(11.50\right.$ to $\left.18.40 \mathrm{cmol}^{(\mathrm{p}+)} \mathrm{kg}^{-1}\right)$ and soil micro-nutrients ranged from $\mathrm{Fe}\left(1.05\right.$ to $\left.3.91 \mathrm{mg} \mathrm{kg}^{-1}\right), \mathrm{Mn}$ (3.34 to $\left.18.28 \mathrm{mg} \mathrm{kg}^{-1}\right), \mathrm{Zn}\left(0.21\right.$ to $\left.2.95 \mathrm{mg} \mathrm{kg}^{-1}\right), \mathrm{Cu}$ (1.05 to $\left.7.95 \mathrm{mg} \mathrm{kg}^{-1}\right)$ and $\mathrm{B}\left(0.5\right.$ to $\left.1.90 \mathrm{mg} \mathrm{kg}^{-1}\right)$ were observed. The results showed that, these soil macro and micro nutrients ranges are also beneficial to the fruitfulness of tamarinds. Hence, it can be concluded that, there is no effect of soil macro and micro nutrients in unfruitfulness of sole orchard and fruitfulness of bund orchard in tamarind. It might be effect of shading in sole crops for unfruitfulness and in case of bund crop orchards it could get proper aeration and sunlight properly.

\section{Introduction}

Tamarind (Tamarindus indica L.) belongs to family Leguminoceae (Fabaceae) is grown in semi-arid tropical and sub-tropical regions of the world. The fruit is native of Tropical
Africa. The total area under cultivation of tamarind in India in the year 2016-17 is 186000 hectares and production is 943000 MT according to National Horticulture Board (Anonymous, 2017). Tamarind thrives best in loamy, deep, well drained alluvial soil, which 
favours the development of a long tap root (Galang, 1955). The optimum $\mathrm{pH}$ of tamarind is 5.5-6.8, which is slightly acidic (FAO, 1988), through it also grows well in alkaline soils. The agriculture by-product like tamarind seed kernel can be used as a cheap source for functional food to increase the added value of tamarind seeds (Mohamed et $a l ., 2015)$. It is a large evergreen tree with an exceptionally beautiful spreading crown and is cultivated throughout almost the whole country, except in the Himalayas and western dry regions (Rao et al., 1999). Almost all parts of the tree find some use or the other in food, chemical, pharmaceutical, textile industries, and as fodder, timber and fuel (Dagar et al., 1995). Tamarind is rich in nutrients and plays an important role in human nutrition, mainly in the developing countries (Mohamed and Rangappa, 1992) and (Yanez et al., 1995). Tamarind is valued mostly for its fruit, especially the pulp, which is used for a wide variety of domestic and industrial purposes (Kulkarni et al., 1993). Seed is a by-product of the commercial utilization of the fruit; the seed comprises the seed coat or testa (20-30\%) and the kernel or endosperm (70-75\%) (Shankaracharya, 1993). It is valued for making gunpowder (Chaturvedi, 1985). Deficient nutrient not only reduces the productivity of the crops but also reduce the use efficiency of applied nutrients. However, information on the optimum range of soils physico-chemical properties and plant for maintaining yield potential and quality of fruit in vertisols and associated black soil of Maharashtra is lacking.

\section{Materials and Methods}

The survey of randomly selected twenty tamarind orchards of eight to thirty five years age planted at different spacing ranging from $8 \times 8 \mathrm{~m}$ to $10 \times 10 \mathrm{~m}$ with plant density of 100 to 150 plant $\mathrm{ha}^{-1}$ at Latur during the year 2017-2018. Soil samples collected during
May 2017, at depth of up to $90 \mathrm{~cm}$. The framed experiment was concentrated, to assess and find out the soil nutrient status of tamarind orchards, relation between soil nutrients and yield of sole and bund crops and unfruitfulness of sole orchards as compare to bund orchard in tamarind of Marathwada region. $\mathrm{N}$ determined by Alkaline Potassium Permanganate method by using Kelplus distillation unit (Subbiah and Asija, 1956), P determined using double beam US- VIS spectrophotometer with Olsen's method as described by Olsen et al., (1954), K determining using Flame Photometer (Jackson, 1967), Ca, Mg determined by versanate titration method (Jackson, 1973) and $\mathrm{S}$ determined by double beam US- VIS spectrophotometer. Fe, $\mathrm{Mn}, \mathrm{Zn}$ and $\mathrm{Cu}$ using Atomic Absorption Spectrophotometer from Perkins Elmer as described by Lindsay and Norvell (1978). B in soil sample by using Azomethine-H on spectrophotometer at 420 nm wavelength (Gupta, 1979).The statistical analysis of the data in respect of soil nutrients was done according to the standard procedure given by Panse and Sukhatme (1985).

\section{Results and Discussion}

\section{Macronutrient status of soil}

It is revealed from the data (Table 1 and Figure 1); In sole planting the soil macronutrients ranges, $\mathrm{N}$ (129.28 to 250.00 $\left.\mathrm{kg} \mathrm{ha}^{-1}\right), \mathrm{P}\left(11.00\right.$ to $\left.38.00 \mathrm{~kg} \mathrm{ha}^{-1}\right), \mathrm{K}(172.00$ to $\left.998.00 \mathrm{~kg} \mathrm{ha}^{-1}\right), \mathrm{Ca}\left(19.00\right.$ to $55.23 \mathrm{cmol}^{(\mathrm{p}+)}$ $\left.\mathrm{kg}^{-1}\right), \mathrm{Mg}\left(186.00\right.$ to $397.00^{(\mathrm{p}+)} \mathrm{kg}^{-1}$ ) and $\mathrm{S}$ $\left(11.25\right.$ to $\left.18.00^{(\mathrm{p}+)} \mathrm{kg}^{-1}\right)$ were observed in the soils of tamarind orchards of Latur district. However, in bund planting, N (137.25 to $258.01 \mathrm{~kg} \mathrm{ha}^{-1}$ ), $\mathrm{P}$ (11.01 to $37.25 \mathrm{~kg} \mathrm{ha}^{-1}$ ), $\mathrm{K}$ (178.11 to $998.80 \mathrm{~kg} \mathrm{ha}^{-1}$ ), Ca (19.20 to 55.80 $\left.\mathrm{cmol}^{(\mathrm{p}+)} \mathrm{kg}^{-1}\right), \mathrm{Mg}\left(197.80\right.$ to $395 \mathrm{cmol}^{(\mathrm{p}+)}$ $\mathrm{kg}^{-1}$ ) and $\mathrm{S}$ (11.50 to $\left.18.40 \mathrm{cmol}^{(\mathrm{p}+)} \mathrm{kg}^{-1}\right)$ were observed in the soils of tamarind orchards of Latur district. 
Table.1 Soil macronutrient status of tamarind orchard of Latur district

\begin{tabular}{|c|c|c|c|c|c|c|c|c|c|c|c|c|c|}
\hline \multirow[t]{2}{*}{ Sr. No. } & \multirow[t]{2}{*}{ Orchard No. } & \multicolumn{2}{|c|}{$\begin{array}{l}\text { Nitrogen } \\
\left(\mathrm{kg} \mathrm{ha}^{-1}\right)\end{array}$} & \multicolumn{2}{|c|}{$\begin{array}{l}\text { Phosphorous } \\
\left(\mathrm{kg} \mathrm{ha}^{-1}\right)\end{array}$} & \multicolumn{2}{|c|}{$\begin{array}{c}\text { Potassium } \\
\left(\mathrm{kg} \mathrm{ha}^{-1}\right)\end{array}$} & \multicolumn{2}{|c|}{$\begin{array}{c}\text { Calcium } \\
\left(\mathrm{cmol}^{\left(\mathrm{p}^{+}\right)} \mathbf{k g}^{-1}\right)\end{array}$} & \multicolumn{2}{|c|}{$\begin{array}{l}\text { Magnesium } \\
\left(\mathrm{cmol}^{\left(\mathrm{p}^{+}\right)} \mathbf{k g}^{-1}\right)\end{array}$} & \multicolumn{2}{|c|}{$\begin{array}{c}\text { Sulphur } \\
\left(\mathrm{cmol}^{(\mathbf{p}+)} \mathbf{k g}^{-1}\right)\end{array}$} \\
\hline & & sole & bund & sole & bund & sole & bund & sole & bund & sole & bund & sole & bund \\
\hline 1 & LTO-1 & 150.00 & 150.95 & 13.00 & 12.98 & 298.00 & 293.15 & 48.00 & 48.25 & 246.90 & 246.80 & 11.89 & 11.85 \\
\hline 2 & LTO-2 & 200.00 & 200.81 & 23.00 & 22.25 & 427.61 & 427.15 & 34.00 & 34.21 & 291.20 & 299.00 & 11.25 & 11.80 \\
\hline 3 & LTO-3 & 168.68 & 163.21 & 22.98 & 24.95 & 186.00 & 186.95 & 19.34 & 19.20 & 295.65 & 295.24 & 15.87 & 11.90 \\
\hline 4 & LTO-4 & 137.00 & 137.25 & 38.00 & 32.15 & 356.81 & 356.00 & 48.28 & 40.30 & 337.52 & 331.92 & 14.37 & 14.90 \\
\hline 5 & LTO-5 & 175.00 & 175.81 & 22.90 & 22.28 & 984.00 & 984.15 & 44.00 & 44.21 & 197.12 & 197.80 & 12.50 & 18.40 \\
\hline 6 & LTO-6 & 168.25 & 163.15 & 22.00 & 23.01 & 906.00 & 906.85 & 36.86 & 36.55 & 277.76 & 277.00 & 16.62 & 15.80 \\
\hline 7 & LTO-7 & 175.00 & 178.09 & 29.38 & 28.95 & 988.80 & 988.50 & 19.00 & 19.75 & 268.00 & 268.11 & 15.80 & 14.97 \\
\hline 8 & LTO-8 & 163.00 & 163.25 & 18.00 & 17.80 & 937.24 & 927.00 & 55.23 & 55.80 & 336.00 & 330.00 & 16.90 & 16.87 \\
\hline 9 & LTO-9 & 150.90 & 150.01 & 16.80 & 16.25 & 934.00 & 935.15 & 51.20 & 51.25 & 186.00 & 198.28 & 14.23 & 14.80 \\
\hline 10 & LTO-10 & 163.25 & 163.91 & 11.50 & 11.25 & 934.00 & 934.68 & 49.20 & 49.21 & 336.00 & 336.11 & 15.00 & 16.25 \\
\hline 11 & LTO-11 & 235.00 & 225.01 & 11.00 & 11.50 & 933.00 & 938.23 & 52.40 & 54.45 & 262.10 & 268.11 & 17.25 & 11.50 \\
\hline 12 & LTO-12 & 175.80 & 175.25 & 14.00 & 14.01 & 974.00 & 947.15 & 40.00 & 40.21 & 395.69 & 395.00 & 18.00 & 13.25 \\
\hline 13 & LTO-13 & 168.28 & 163.21 & 13.00 & 18.25 & 974.00 & 974.75 & 37.23 & 37.20 & 256.40 & 246.00 & 15.00 & 15.12 \\
\hline 14 & LTO-14 & 250.00 & 258.01 & 25.00 & 25.01 & 616.80 & 616.20 & 38.29 & 38.15 & 194.40 & 246.00 & 14.00 & 13.50 \\
\hline 15 & LTO-15 & 163.08 & 165.01 & 22.24 & 22.11 & 917.00 & 911.25 & 48.80 & 48.15 & 268.80 & 268.4 & 15.11 & 15.83 \\
\hline 16 & LTO-16 & 188.09 & 188.02 & 28.00 & 25.21 & 998.00 & 998.80 & 36.80 & 36.50 & 351.52 & 351.00 & 14.10 & 14.80 \\
\hline 17 & LTO-17 & 150.00 & 180.01 & 31.79 & 37.25 & 818.00 & 818.95 & 44.39 & 44.15 & 397.00 & 391.24 & 13.18 & 18.00 \\
\hline 18 & LTO-18 & 163.00 & 165.29 & 18.00 & 18.81 & 848.00 & 845.61 & 50.10 & 50.75 & 352.00 & 351.11 & 15.00 & 12.15 \\
\hline 19 & LTO-19 & 188.25 & 188.11 & 13.00 & 13.25 & 925.00 & 923.00 & 40.28 & 40.30 & 268.00 & 294.25 & 14.91 & 14.23 \\
\hline 20 & LTO-20 & 129.28 & 139.20 & 17.00 & 11.01 & 172.00 & 178.11 & 50.28 & 50.21 & 387.00 & 378.15 & 14.95 & 15.80 \\
\hline & Mean & 173.09 & 174.67 & 20.52 & 20.414 & 756.41 & 754.58 & 42.68 & 41.94 & 295.25 & 298.47 & 14.79 & 14.58 \\
\hline & Range & $\begin{array}{l}129.28- \\
250.00\end{array}$ & $\begin{array}{c}137.25- \\
258.01\end{array}$ & $\begin{array}{l}11.00- \\
38.00\end{array}$ & $\begin{array}{l}11.01- \\
37.25\end{array}$ & $\begin{array}{l}\text { 172.00- } \\
998.00\end{array}$ & $\begin{array}{l}\text { 178.11- } \\
998.80\end{array}$ & $\begin{array}{l}19.00- \\
55.23\end{array}$ & $\begin{array}{l}19.20- \\
55.80\end{array}$ & $\begin{array}{l}186.00- \\
397.00\end{array}$ & $\begin{array}{l}197.80- \\
395.00\end{array}$ & $\begin{array}{l}11.25- \\
18.00\end{array}$ & $\begin{array}{l}11.50- \\
18.40\end{array}$ \\
\hline & SE \pm & 164.51 & 166.02 & 19.51 & 19.40 & 718.93 & 717.19 & 40.06 & 39.86 & 280.62 & 271.38 & 14.06 & 13.86 \\
\hline
\end{tabular}

LTO: Latur Tamarind Orchards 
Table.2 Soil micronutrient status of tamarind orchard of Latur district

\begin{tabular}{|c|c|c|c|c|c|c|c|c|c|c|c|}
\hline \multirow[t]{2}{*}{ Sr. No. } & \multirow[t]{2}{*}{$\begin{array}{l}\text { Orchard } \\
\text { No. }\end{array}$} & \multicolumn{2}{|c|}{$\begin{array}{c}\text { Iron } \\
\left(\mathrm{mg} \mathrm{kg}^{-1}\right)\end{array}$} & \multicolumn{2}{|c|}{$\begin{array}{c}\text { Manganese } \\
\left(\mathrm{mg} \mathrm{kg}^{-1}\right)\end{array}$} & \multicolumn{2}{|c|}{$\begin{array}{c}\text { Copper } \\
\left(\mathrm{mg} \mathrm{kg}^{-1}\right)\end{array}$} & \multicolumn{2}{|c|}{$\begin{array}{c}\text { Boron } \\
\left(\mathrm{mg} \mathrm{kg}^{-1}\right)\end{array}$} & \multicolumn{2}{|c|}{$\begin{array}{c}\text { Zinc } \\
\left(\mathrm{mg} \mathrm{kg}^{-1}\right)\end{array}$} \\
\hline & & sole & bund & sole & bund & sole & bund & sole & bund & sole & bund \\
\hline 1 & LTO-1 & 3.91 & 3.15 & 17.91 & 11.90 & 3.80 & 3.20 & 0.91 & 0.50 & 1.85 & 1.15 \\
\hline 2 & LTO-2 & 2.50 & 2.85 & 10.00 & 18.28 & 1.50 & 1.05 & 1.40 & 1.85 & 0.31 & 0.85 \\
\hline 3 & LTO-3 & 3.50 & 3.61 & 16.81 & 16.88 & 3.50 & 5.15 & 0.20 & 0.85 & 0.86 & 0.41 \\
\hline 4 & LTO-4 & 2.21 & 2.95 & 19.38 & 9.30 & 3.28 & 3.80 & 0.82 & 0.81 & 2.79 & 2.95 \\
\hline 5 & LTO-5 & 2.51 & 2.85 & 15.00 & 15.95 & 7.58 & 7.00 & 0.50 & 0.25 & 1.79 & 1.90 \\
\hline 6 & LTO-6 & 2.15 & 1.20 & 13.50 & 3.34 & 3.20 & 2.25 & 0.89 & 0.40 & 0.80 & 0.35 \\
\hline 7 & LTO-7 & 3.00 & 3.88 & 14.10 & 14.75 & 7.00 & 7.95 & 0.40 & 0.59 & 0.60 & 0.21 \\
\hline 8 & LTO-8 & 1.99 & 1.29 & 16.50 & 15.25 & 2.15 & 3.20 & 0.85 & 0.30 & 1.00 & 1.89 \\
\hline 9 & LTO-9 & 3.92 & 3.15 & 7.98 & 7.25 & 2.80 & 2.15 & 0.88 & 0.60 & 0.30 & 0.85 \\
\hline 10 & LTO-10 & 1.20 & 1.75 & 16.28 & 15.30 & 6.00 & 6.95 & 0.40 & 0.55 & 0.48 & 0.95 \\
\hline 11 & LTO-11 & 2.00 & 2.95 & 8.50 & 9.51 & 4.00 & 4.81 & 0.28 & 0.89 & 1.00 & 1.86 \\
\hline 12 & LTO-12 & 3.85 & 3.48 & 16.11 & 15.15 & 6.28 & 6.25 & 0.28 & 0.85 & 0.80 & 0.58 \\
\hline 13 & LTO-13 & 2.58 & 1.59 & 14.81 & 15.83 & 4.00 & 5.11 & 0.22 & 0.80 & 0.21 & 0.75 \\
\hline 14 & LTO-14 & 2.88 & 2.95 & 18.39 & 13.35 & 1.30 & 2.35 & 0.95 & 0.21 & 1.50 & 1.85 \\
\hline 15 & LTO-15 & 1.50 & 1.05 & 3.51 & 8.48 & 2.40 & 2.85 & 0.52 & 0.98 & 1.28 & 1.89 \\
\hline 16 & LTO-16 & 2.20 & 2.25 & 19.78 & 14.74 & 2.94 & 2.11 & 1.11 & 1.90 & 0.50 & 0.88 \\
\hline 17 & LTO-17 & 2.91 & 3.91 & 11.48 & 17.45 & 8.60 & 3.65 & 0.50 & 0.75 & 0.38 & 0.88 \\
\hline 18 & LTO-18 & 2.35 & 2.80 & 14.80 & 14.89 & 5.88 & 5.35 & 0.17 & 0.80 & 0.21 & 0.75 \\
\hline 19 & LTO-19 & 1.81 & 1.35 & 18.45 & 17.49 & 8.11 & 3.95 & 0.88 & 0.60 & 1.15 & 1.60 \\
\hline 20 & LTO-20 & 2.84 & 3.81 & 6.11 & 6.98 & 4.98 & 5.90 & 0.40 & 0.80 & 0.88 & 0.30 \\
\hline \multicolumn{2}{|c|}{ Mean } & 2.59 & 2.64 & 13.97 & 13.10 & 4.46 & 4.25 & 0.62 & 0.76 & 0.93 & 1.14 \\
\hline \multicolumn{2}{|c|}{ Range } & $1.20-3.92$ & $1.05-3.91$ & $3.51-19.78$ & $3.34-18.28$ & $1.30-8.60$ & $1.05-7.95$ & 0.17-1.40 & $0.50-1.90$ & 0.21-2.79 & $0.21-2.95$ \\
\hline \multicolumn{2}{|c|}{$\mathbf{S E} \pm$} & 2.46 & 2.51 & 13.27 & 12.45 & 4.24 & 4.00 & 0.59 & 0.72 & 0.88 & 1.08 \\
\hline
\end{tabular}


Fig.1 Planting of sole and bund orchards

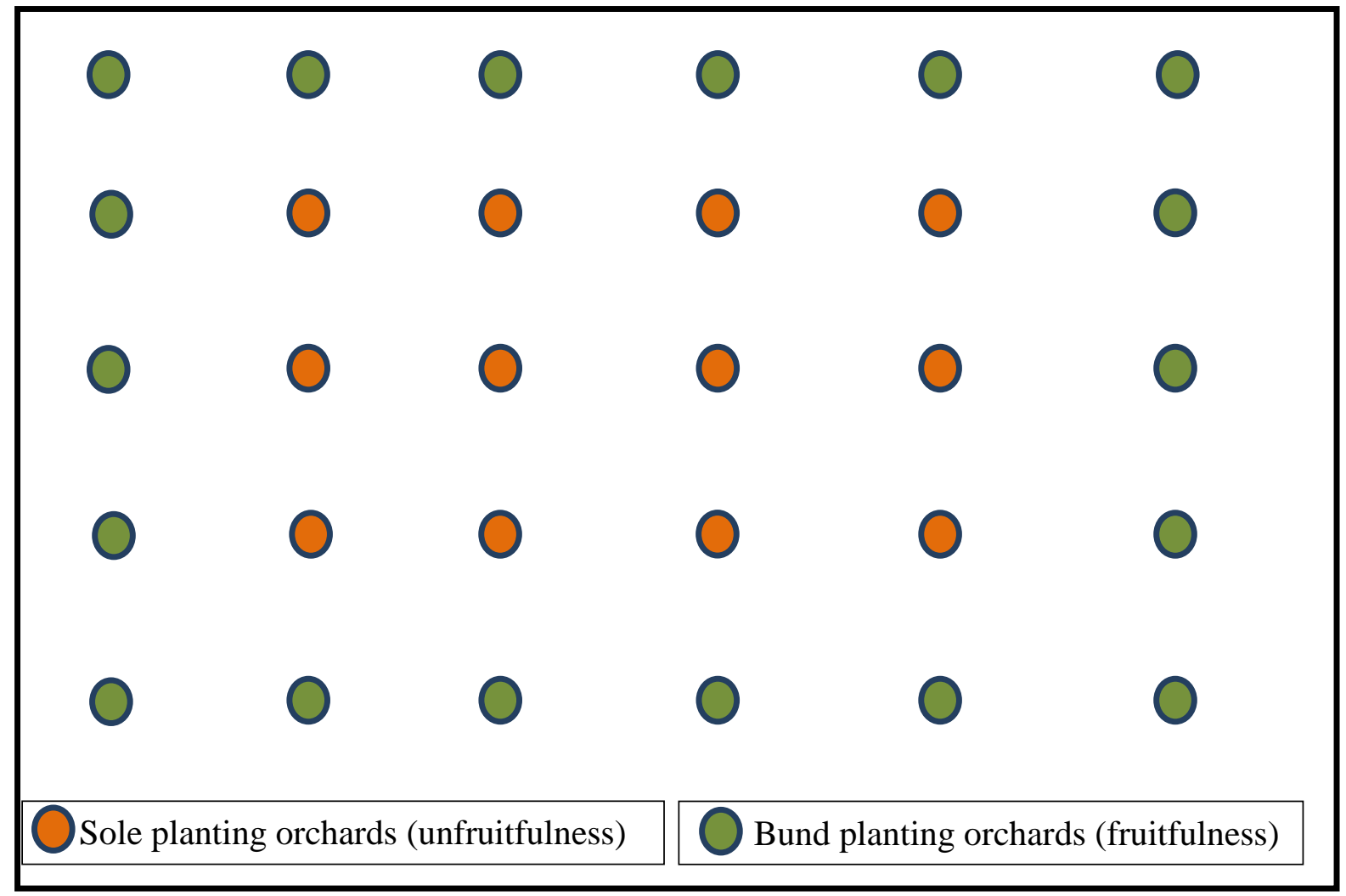

Same results were also recorded by Parwe (2013) in the pomegranate orchards of Beed district.

\section{Micronutrient status of soil}

It is revealed from the data (Table 2 and Figure 1); In sole planting the soil micro nutrients ranges, $\mathrm{Fe}\left(1.20\right.$ to $\left.3.92 \mathrm{mg} \mathrm{kg}^{-1}\right)$, $\mathrm{Mn}$ (3.51 to $\left.19.78 \mathrm{mg} \mathrm{kg}^{-1}\right), \mathrm{Cu}$ (1.30 to 8.60 $\left.\mathrm{mg} \mathrm{kg}{ }^{-1}\right), \mathrm{B}$ (0.17 to $1.40 \mathrm{mg} \mathrm{kg}^{-1}$ ) and $\mathrm{Zn}$ ( 0.21 to $2.79 \mathrm{mg} \mathrm{kg}^{-1}$ ) were observed in the soils of tamarind orchards of Latur district. However, in bund planting, Fe (1.05 to 3.91 $\mathrm{mg} \mathrm{kg}$ ), Mn (3.34 to $18.28 \mathrm{mg} \mathrm{kg}^{-1}$ ), $\mathrm{Zn}$ (0.21 to $\left.2.95 \mathrm{mg} \mathrm{kg}^{-1}\right), \mathrm{Cu}$ (1.05 to $7.95 \mathrm{mg}$ $\left.\mathrm{kg}^{-1}\right)$ and $\mathrm{B}$ (0.5 to $\left.1.90 \mathrm{mg} \mathrm{kg}^{-1}\right)$ were observed in the soils of tamarind orchards of Latur district. Similar result was found by Parwe (2013) in pomegranate orchards of Beed district.
It is concluded that, in Marathwada region, the soils macro and micro nutrients are available in sufficient range and also beneficial to increase of growth, yield and quality of tamarind, but in this region yield and quality was not found in sufficient range, it may be due to shedding effect, irregular rainfall, soil moisture availability lack of harvesting knowledge, etc.

\section{References}

Anonymous, 2017. Area and Production of Horticulture Crops in India. Indian Horticulture Database, National Horticulture Board.

Chaturvedi, A.N., 1985. India Government of India Press. Firewood farming on the degraded lands of the Gangetic plain, Lucknow (U.P.) Forest Bulletin No.50, 1: 286 . 
Dagar, J.C., Singh, G. and Singh, N.T., 1995. Evolution of crops in agroforestry with Teak (Tectoma grandis), Maharukh (Ailanthus excelsa) and Tamarind (Tamarindus indica) on reclaimed saltaffected soils. Journal Tropical Forest Science, 7: 623-34.

FAO, 1988.Food and Agriculture organization. Rome, Italy.

Galang, F.G. 1955. Fruits and Nuts Grown in the Philippines. Malabon, Rizal AIA Printing Press.

Gupta, U.C., 1979. Some factors affecting determination of hot water soluble boron from podzol soils using Azomethine-H. Can. J. Soil. Sci., 59: 241-247.

Jackson, M.L., 1967. Soil chemical analysis Prentice hall of India Pvt. Ltd., New Delhi, pp-205.

Jackson, M.L., 1973. Soil chemical analysis, Prentice Hall of India Pvt. Ltd. New Delhi, pp-498.

Kulkarni, R.S., Gangaprasad, S. and Swamy, G.S., $\quad 1993 . \quad$ Tamarindusindica: Economically an important minor forest product. Minor Forest Prod News, 3: 6.

Lindsay, W.L. and Norvell, W.A., 1978. Development of DTPA soil test for Zn, $\mathrm{Fe}, \mathrm{Mn}$ and $\mathrm{Cu}$. Soil Sci. America. J. 42: 421-428.

Mohamed, A.I. and Rangappa, M., 1992.Screening soybean (grain and vegetable) genotypes for nutrients and antinutritional factors. Plant Foods Hum Nutr., 42 87-96.
Mohamed, HA., Mohamed, BE. and Ahmed, KE., 2015. Physicochemical properties of tamarind (Tamarindus indica L.) seed polysaccharides. Journal Food Process Technology, ISSN: 2157-7110.

Olsen, S.R., Cole, C.V., Watanbe, F.S. and Dean, L.A. 1954. Estimation of available phosphorus in soils of Vidharbha, Maharashtra. J. Maharashtra Agric. Univ. 28(1): 3-7.

Panse, V.G. and Sukhatme, P.N. 1985. Statistical methods for Agricultural workers. IARI, New Delhi.

Parwe, S K. 2013. Nutritional evaluation of pomegranate orchards of south-east region Beed district by soil and leaf analysis. M. Sc. (Agri.) thesis submitted to MAU, Parbhani.

Rao, Y.S., Mathew, M.K. and Potty, S.N., 1999. Tamarindus indica. Indian journal of arecanut, spices and medicinal plants, 1: $127-45$.

Shankaracharya, N.B., 1998. TamarindChemistry, Technology and Uses - a critical appraisal. Journal Food Technology, 35: 193-208.

Subbiah, B.V. and Asija, G.L. 1956. Rapid procedure for the determination of available nitrogen in soil. Curr. Sci. 25: 259-260.

Yanez, E., Zacarias, I., Aguayo, M., Vasquez, M. and Guzman, E., 1995. Nutritive value evaluation Rats of new cultivars of common beans (Phaseolus vulgaris) released on Chile. Plant Foods Hum Nutr., 47: 301-307.

\section{How to cite this article:}

Urade, P.S., R.M. Dheware and Jadhav, A.R. 2019. Studies on Effect of Soil Macro and Micronutrient Status of Tamarind (Tamarindus indica L.). Int.J.Curr.Microbiol.App.Sci. 8(02): 671-676. doi: https://doi.org/10.20546/ijcmas.2019.802.076 